\title{
THE PARLIAMENTS OF CANADA AND PAKISTAN: A COMPARATIVE ANALYSIS OF STRENGTHS AND WEAKNESSES
}

\author{
Sidra Akram ${ }^{1}$, Mian Muhammad Azhar ${ }^{2 *}$, Shakil Akhtar ${ }^{3}$, Husni Mubarak ${ }^{4}$, Muhmmad Ikram Ul Haq ${ }^{5}$ \\ ${ }^{1}$ Ph.D., Research Scholar, Department of Political Science \& IR, Government College University, Faisalabad, Pakistan; \\ ${ }^{2 *}$ Assistant Professor, Department of Political Science \& IR, Government College University, Faisalabad, Pakistan; \\ ${ }^{3}$ Assistant Professor, Department of Political Science, The Islamia University of Bahawalpur, Pakistan; ${ }^{4}$ Associate Lecturer, \\ Department of Political Science, The Islamia University of Bahawalpur, Pakistan; ${ }^{5}$ Research Scholar, Department of \\ Computer Science, University of Agriculture, Faisalabad, Pakistan. \\ Email: "muhammad.azhar@gcuf.edu.pk
}

Article History: Received on $11^{\text {th }}$ May 2021, Revised on $16^{\text {th }}$ May 2021, Published on $23^{\text {rd }}$ May 2021

\begin{abstract}
Purpose: The main purpose of this study is to make a deeper analysis of the parliament of Canada and Pakistan. This research deals with comparing two similar parliamentary systems. The two countries, i.e. Canada and Pakistan were chosen because of their majority electoral system and to a lesser extent, alike political trends. This research analyzed the weaknesses and strengths of both the legislative systems.
\end{abstract}

Method: Data related to this topic has been collected from secondary sources such as reports, journal articles, and books. This research work is analytical as well as descriptive in nature. Qualitative techniques have been applied to investigate the research questions.

Main Findings: This study acknowledges that the parliamentary form of government is the most representative and most efficient system of government that is running successfully in different countries. Parliament safeguards the political views of the citizens and thus provides them with all possible opportunities for more participation in the government. It creates a cohesive and strong party system. The main finding to be acquired from this study is that one problem that is common to both nations is provincial imbalance. However, overall it can be said that Canada has accommodated its provinces effectively through its responsible government, democratic system, and granting maximum autonomy. Another factor that is a major problem in Pakistan but not so in Canada is the branches of government overstepping their jurisdiction.

Application of the Study: Using the yardstick of the function of legislation and making comparative references with other political systems was very useful in summarizing this research. Whatever weaknesses and criticisms may be discussed the overall fact is that the job done by these parliaments is undoubtedly necessary and useful and it is hoped this study may serve as a guideline for future parliaments to make them more efficient.

The Originality of the Study: This research argues that a parliamentary system is a more desirable and efficient system of government than others. This research explains the differences between both these systems. Both the houses of these parliaments provide separate services that require separate investigation and throw further light on the subject.

Keywords: Parliament, Canada \& Pakistan, The Legislative Process, Parliamentary Form of Government, Westminster System.

\section{INTRODUCTION}

The parliament is the constitutional expression of the order of society. The parliament of any state defines the functions of the government and sets out these functions in the constitution of the state; gives a voice to the aspirations of the people in almost all policy matters of the government; handles and resolves internal threats and crises and also protects the basic rights of the people (Oldenburg,2011). Many countries in the world have adopted the parliamentary form of government in which constitutionally the executive has to answer to the parliament. Some apply the word parliament to the proper parliamentary system, while many others employ this word for any elected body of the legislature, like the parliaments in some Sheikhdoms in the Middle East. Although, the prime minister in some parliamentary forms of governments is not a member of the parliament, such as in the Netherlands, while in others he is a regularly elected member; which is usually the case such as in the UK. Parliament is acknowledged as the pivotal institution of democracy (Zaka M. R., 2018). The main argument supporters of the parliamentary systems make is that this form of government tends to collapse into dictatorship a lot less than presidential systems. This point was most pertinently made in 1990 by the late Yale political scientist Juan Linz (Mahboob H. U., 2020). Also, parliamentary governments enact more left-wing policies than other governments. Despite some critics of Linz's theory, history has shown that presidential systems upsurge the menace of democratic breakdown and this is further borne out when you consider the fact that presidential democracies are more likely to sprout up in countries with histories of military coups (Ahmed N., 2020). 
In particular, there is a reason for leftists and liberals to favor parliamentary government: It is inclined to escort to better government spending and particularly to more equitable re-distribution of capital than the alternative (Schoburgh, 2016). Hence, with a proportional representation, the parliamentary governments spend more than majoritarian presidential governments on welfare coasts like the United States. Regarding parliamentary systems in the world, one is particularly commendable and functioning smoothly, manifesting in practice a balanced combination of virtues, new ideas, principles, conventions, and rules that evolve daily and that reflect the spirit of the times as well as the realities, and above all the will of the people (Ahmad M., 2017). That is the tried and tested British Parliamentary system that has been functioning for 700 years and is still being shaped and perfected. Under its auspices, the voice of the masses through the people they elect to represent them in the House of Commons is supreme (Tushnet \& Khosla, 2015).

The unique British parliamentary democracy, with its unwritten constitution, is in conception and practice the system that truly asserts the principles of democracy. Under this magnificent paradigm, the executive is completely responsible and subservient to the legislature and thereby to the people (Khalid M. T., 2018). With the congressional system, this is not so. The president is not held accountable to congress to answer debates regarding his actions as is the prime minister under the British system. In case, the British legislature feels that the executive is not working in the public interest actually, then it can stop the support. For example, in his speech, the executive must present his policies to the parliament and be ready to defend them after detailed scrutiny not only by members of the opposition but also by backbenchers (Kokhar, 2017). All public spending must be approved by parliament, which, if deemed appropriate, can block the ban. If that happened then the administration would have to resign. If nothing new is found, then once again the people have the power to decide through an electoral process to elect for parliament a new entity of members (Burki, 2010). Hence this research answers the following research questions:

RQ1: How does Parliament work in Canada and Pakistan and make use of their strengths to enhance parliamentary competency?

RQ2: How Parliaments of both these countries overcome their weaknesses by making use of available resources which make them better than others?

\section{REVIEW OF LITERATURE}

Some of these books and articles which are more relevant to the specific research are mentioned below:

Abbasi A. A., 2018 emphasized the covering of all those factors that are involved in the weakness of the democratic system and good governance. The study also focuses on the reasons for a gap between the parliamentary institutions and their citizens.

Khalid M. T., 2018 wrote in this article about the post-legislative scrutiny is the laws evaluating act and passed by the parliament. He further describes in detail the reasons and process for Post-Legislative Scrutiny and presents pertinent trends and facts in preferred countries and opportunities identifies in this comparative study which is related to the organization of democracy assistance and parliamentary strengthening programming of the Westminster Foundation for Democracy (WFD). The provided data also present the concept not completely but partly beneficial information in this research.

Hashmi, 2018.demonstrates in the article that the concept of Parliamentary Sovereignty and Democracy and the South Asian institutional jurisdiction issues which are referred to as Legislative Supremacy and Supremacy of Parliament and deals with more than a few concurrent ethics. He discussed the whole models of parliamentary sovereignty in detail and gives all the basic tools which are helpful for the completion of the proposed research work. This makes it a complex idea to clutch in its whole.

Ahmad M., 2017 stated that the parliamentary contribution to pursue important issues faced by the citizens and curb them with suitable amendments in his paper. The paper is helpful to highlight the effective and active role of the National Assembly and Senate by utilizing resolutions, law-making, parliamentary tools, and committees.

Palonen M., 2016 said that the origin of the parliamentary system can be traced out from the concept of the Westminster political system. He writes that the Canadian parliamentary system is based on the British parliamentary system that is called the Westminster System, a style of democracy adapted from centuries of English tradition. In the world, the British had the best organization of government assumed by Canada's organizers.

Hussain, 2013 analyzed in the article that deliberative assemblies, legislative, and Representative are usually called parliaments. He says these three types split a lot of practices and procedures of assembly and included between their members. However, these types do differ in their methods of thinking and acting politically. This article provides relevant information on parliamentary politics but does not fill the requirements of the proposed topic. 
Rodger, 2013 Rodger discussed the role of Parliament in implementation, monitoring, and evaluating legislation. He says when laws are made by the Parliament then they achieved their intended importance. He said the main role of Parliament is to monitor the legislation, he said basically laws implementation is complex tasks that automatically do not happen

Johnston, 2012 gave an introduction to the Modern Democratic State in this book and states that many types of government explain the book comprehensively. He wrote that Parliament is an integral part of the legislative procedure. Though, the abilities to start the regulation can be found with professional, the part of the parliament in deliberating and improving the final result.

Whittington \& Loon, 2011 explored over the past 150 years, a window on how the traditions, practices, and procedures of the House of Commons and have evolved the role of its Members. In this book, Bosc \& Gagnon gives the vital parliamentary implications of its theory for constitutional and statutory interpretation. In Canada, the book is central to the practice of law.

Tidridge N., 2011 stated in his book that the Queen fills her role as the Head of the State in the Canadian political system and performed every act of government. Hence, the premiers and prime ministers also perform their jobs as elected members of the Parliament in Canada. The Crown is a symbol, concept, or abstract which represents the government and state. The sixpart of this book consisted of Federalism, institution, a constitutional history, constitutional theory which is helpful to understand the proposed topic.

James \& Kasoff, 2008. talked about the Canadian nation as a discrete benefit more than ever in the book. He stated that Canada's constitutional monarchy should be precious. In the book, he discussed the tasks of the Governor-General, the Queen, and the lieutenant governor significance, in the institution of the Crown in the New Millennium in Canada.

\section{METHODOLOGY}

Data related to this topic has been collected from secondary sources such as reports, articles, books, and journals. This research work is analytical as well as descriptive in nature. The method of comparing the traditional parliamentary system of two countries presents a new perspective of the subject that gives an expanded view and enables more meaningful research. Hence, the Qualitative technique has been applied to investigate the research questions.

\section{DISCUSSION /ANALYSIS}

\section{Role of parliament}

Parliament is said to play the most important role as an institution. Being an imperative module of the national governance system, it performs some key functions including legislation, representation, and oversight. It can contribute to the elements of operative governance effectively by playing these roles: responsiveness, accountability, and state capability. In terms of laws formulating, inspecting the governmental activities, debating national issues, and generally stimulating the citizen's welfare, these obligations and duties are performed rarely with effectiveness and efficiency by the parliament across the world. Parliament can be a link between local and global issues, defenders of human rights, and pillars of democracy.

The parliamentary system works effectively. This is evident in how it handles ministerial responsibilities and cabinet appointments. Under a parliamentary system, an elected parliament chooses the cabinet ministers. As the cabinet for their actions shares collective responsibility and must defend both its departments and the administration in the parliament. The parliamentary system permits the representation of small ethnic groups and various minorities in the legislature, whether through the formation of their parties or a party-established system (Ali \& Ejaz, 2020). It can form political parties that are ideologically and radically different from the established parties or the ruling party. This has led to the formation of the New Democratic Party, a minority political entity in Canada, which has had a profound effect on Canadian politics and Canadian society. The flexibility of the electoral system in Great Britain has seen the Labor Party replace with the Liberal Party as one of the two major political engines of the country and the other one being the Conservatives. People vote for a leader or a party and they expect to form a government in a parliamentary system (Hashmi, 2018). Hence, it is the beauty of this parliamentary system that the opposition and the government sit together in one legislature, yet the opposing points of view represented by the opposition positively and considered by the governing party. There can be no healthier political system that achieves political independence ultimately, where each party is subject to the will of its constituency and therefore both parties (governing and opposition) strive to represent the people at all times (Huntington, 2012).

\section{Westminster system}

As former colonies of Britain, Canada and Pakistan inherited the British style of governance called the Westminster system. Hence, both the parliamentary system of Canada and Pakistan stem from the British tradition of Westminster (Sultana T., 2017). This system was used in the palace of Westminster stipulating a code of procedures for operating a legislature. The origin of all parliamentary systems can be traced to the concept of the Westminster political system. It was the one installed in the sub-national or national legislatures of the former colonies of the British Empire and most of the nations continued 
using it after independence when they became the Commonwealth countries, which includes the provinces of Canada (Barnes, 2019). Other countries adopted it as well. Now, the Westminster system is the prevailing form of governance in Singapore, Pakistan, Canada, Malaysia, New Zealand, Malta, India, Australia, Jamaica, Ireland, Bangladesh, Nepal, Japan, Israel, West Indies, many African and other countries. There is also another parliamentary system of government that is considerably different from that of Westminster in practice, like that functioning in Italy and Germany (Malcolmson P., 2012).

In actual, the Westminster model of parliamentary democracy has its roots in British history. The origin of this system started from the concept of the Westminster system of parliamentary representation and its footprint can be traced back to $13^{\text {th }}$ century England then from Canada, Pakistan, Britain, New Zealand, Australia, India, and other countries (Bourinot J. G., 2008). Hence, the first model of parliament (representative assembly) was summoned by King Edward I in 1295. Often, the early kings of England invited clerics and noblemen to consult with them on significant state matters. These gatherings were interpreted as 'great councils' or 'courts'. In England the king needed the support of his feudal nobility, especially to raise taxes. The lords and barons demanded more power (Barnes A., 2012).

Magna Carta was sealed on June 15, 1215, under documents seeking to limit the king's authority between King John and his English lords, by 1275 . Hence, it was regularly summoned by King Edward-I to burgesses and knights and advised them on financial affairs. In short, it approved the provision of public funds. The Westminster model of parliament began from these great councils of the 13th century (Hall \& McGuire, 2005). In the $14^{\text {th }}$ century, these councils evolved from merely tax matters to redress grievances of people. Sheriffs of towns and other important people sent people to represent them in councils. Thus in the time of Henry IV (r. 1399 to 1413), the beginnings of the House of Commons was formed. Oliver Cromwell (1643 to 1651) deposed and executed King Charles I and for a brief period abolished the monarchy. He needed a pliant parliament of commoners to support him (the 'rump parliament'). Developing social currents like expanding cities and the Industrial Revolution required more attention be given to civic amenities and various other historical events step by step led to the growing power of the prime minister and greater importance of the House of Commons and the Westminster parliamentary system evolved (Green, 2017).

This form of government forms the majority government. This enables the Prime Minister to pass the bill effectively and efficiently as he/she can rely on party members to vote in favour. The type of bureaucracy that is the leader of any majority party is subject to the approval of party policies through the parliamentary system and focuses on specific issues (Heitshusen, 2017). That is the background of the Westminster Parliamentary system which has been adopted by both Canada and Pakistan which we intend to compare. These two countries were chosen as they have similar plurality electoral systems, and similar political orientation. Both Canada and Pakistan's parliamentary systems have their own circumstances. Pakistan is primarily a federally administered, constitutional, and democratic country in nature and is comprised of four provinces and a tribal area that has now been amalgamated in the KP Province. Canada is divided into 13 parts: 3 territories in the northwest and north and 10 other provinces. The difference between a territory and a province is that the territories are grouped together and administered by the federal government and the provinces have their provincial governments (White, et al 2011).

\section{The parliaments of Canada and Pakistan}

Both Pakistan and Canada were colonies of Britain. Pakistan gained independence in 1947. Canada originally had French colonies known as the Maritime colonies along the eastern coast (Smith, et al, 2017). In 1763 the French ceded their Canadian territories to the English. Starting in 1848 'responsible government' was introduced in the provinces of Canada by the British. The Responsible government are legislative cum executive bodies set up in the provinces originally meant to impose colonial rule and take administrative decisions. With the passage of time the franchise of the electoral increased and they became more democratic and independent (Koop, Bastedo, \& Blidook, 2018). Responsible government is a precursor to dominion status. In 1867 with the Constitution Act in 1867 (then called the British North America Act) passed by the British Parliament; three of the five colonial provinces of the British were united, i.e., Ontario, Quebec, and the Maritime Provinces were united into a confederation and granted dominion status and subsequently, the other provinces also joined mainly in the $19^{\text {th }}$ century (the last two in as late as 1999, the frozen Yukon and Nunavut) and received dominion status (Rodger, 2013). The Act of 1867 kept the Canadian Parliament subservient to the British Parliament; it could enact laws for Canada and nullify their legislature if it objected to it. However, gradually the Canadian parliament became more independent. By the end of the $1^{\text {st }}$. World War Canada was virtually independent. In the Westminster Statute of 1931, Canada was given equal legislative status as Britain. In 1982 Canada has officially declared an independent country (Todd \& Horatio, 2015).

Canada is a constitutional monarchy and the Crown is a symbol that represents the government and state. Pakistan has no concept of the monarchy while in Canada's constitutional monarchy the sovereign (currently the Queen of England) acts as the political head of state but his or her powers are kept within the boundaries of that country's constitution and the recommendations of the executive and legislature and the sovereign have to accept their advice (Todd \& Horatio, 2015). The 
Canadians view their identity as a nation from the confederation that started with the Constitution Act in 1867 as well as unwritten conventions and other documents adopted over time and stated that how it would work and who would be involved in the government. In the Canadian democratic system or responsible government, the Crown performs every function of the government through ministers, members of parliament, or judges, whose advice is binding (White, et al, 2011). Thus the queen has a formal and nominal status. However, all laws on the federal level are prepared in the name of the queen. When she visits Canada she performs numerous ceremonial duties while in her absence the Governor-General represents the queen. $\mathrm{He}$ is appointed by the queen on the prime minister's advice. Usually, the governor-general is appointed for a five-year term (Whittington \& Loon, 2011). However, the powers of the queen are either conferred on the Governor-General or delegated such as to grant royal assent, dissolve or prorogue the parliament, summon, dismiss and appoint the prime minister. Apart from this other prerogative powers of the Crown are also performed by the governor-in-council. The governor-in-council is the cabinet acts that in the name of the Governor-General. The sovereign can exercise the constitutional powers of the Crown personally when she is present in Canada especially on historical occasions (Loughlin, Kincaid, \& Swenden, 2013).

The President of Pakistan was given a formal status similar to the queen following the traditions of the parliamentary system. The president is the head of state but does not get real administrative powers while the Governor-General serves as the head of the state in the queen's absence from Canada. The President of Pakistan is elected indirectly for a fixed term of five years by the senate and the national assembly, and the members of all four provincial assemblies whereas the Governor-General appoints by the queen in Canada on the Canadian Prime minister's advice for five years of the term. No method for the removal of Governor-General has been stipulated other than him/her resigning or nominating someone else to take his/her place, while in Pakistan the president can be impeached or he may be dismissed if he is accused of violating the constitution; commits a serious misdemeanour or is unable to perform his duties physically or mentally. The members of the national assembly or the senate can bring an impeachment motion against the president.

\section{Functions of the parliament}

Pakistan and Canada's system of governance have three pillars: the legislative the executive, and judiciary. Being a federation, these three pillars of the government in both these states operate at both the provincial and federal levels. Both countries have constitutionally recognized provincial governments and constitutionally recognized federal government. Each branch of government in both Pakistan and Canada has a specific role to play. The constitutions of the two countries set out the framework for how these branches should work together and operate to serve the nation. Therefore, these three branches of government together provide an essential framework that governs the country's democratic governance.

- Executive: The executive is the very first branch of the political system. The executive is the major department and administers the country. The executive performs its duties through various departments. Therefore, most of the responsibility for collecting taxes and implementing government policy and decisions lies with the administration. Some people give the executive/administration the name 'the government' which is wrong because the executive is only one of the three organs of the government. The term 'the executive' is used by the laity in a limited sense often referring to a boss or manager in the private sector. In its broader sense, the term refers to all bureaucrats and government officials. Altruistically speaking all government officials are part of the executive from the peon to the president or GovernorGeneral, however, more precisely it refers to the body of high officials in the government in all departments, federal and provincial. The executive is like the management of the country in Pakistan and is made up of the prime minister with his cabinet and the bureaucracy or government officials. In Canada, of course, the executive also ostensibly includes the queen. In Canada, the Queen represented by the Governor-General represents and the Prime Minister in the House of Commons is the leader of the political party with majority seats (in Canada the lower chamber is also called The House of Commons). In early Canadian history, the British monarch ruled the area through Parliament in London until Canada became a country in 1867 and eventually enacted its laws through the constitution. Hence, in Canada, the king has since become a symbol of allegiance, authority, and unity to the Crown Prince, a figure with significant symbolic power but little or no decision-making power. Although the Governor-General follows the Prime Minister's advice, the King is still a symbol of allegiance, authority, and unity in Canada (James \& Kasoff, 2008). The King is represented by a LieutenantGovernor in each of the ten provinces and by the Governor-General at the federal level in Canada. Besides, Commissioners are also appointed in each of the three territories (Commons H. o., 2017). They perform the same duties as the lieutenant governors but are not considered representatives of the king and are therefore representatives of the Government of Canada (Johnston, 2012). Hence, the Governor-General appoints the lieutenant governors in each of the provinces for a term of fewer than five years on the advice of the Privy Council of Queen which in effect consists mainly of cabinet ministers (Newman, 2012). The prime minister is the Centre of the administrative machinery in a democracy. In both Pakistan and Canada he is the head of the government, leader of the ruling party as well as chief executive. In Pakistan, after the president is elected he invites an elected member to become the prime minister, usually the leader of the political party who has the most seats in the national assembly. Then the designated candidate must gain a vote of confidence from the national assembly. If he doesn't have a majority he must form a coalition. In Canada, the Governor- 
General appoints the person most likely to enjoy the confidence of the lower house, which normally is the leader of the majority party. If he is not an elected member of the house, e.g. a senator or he may have lost his election though his party won, then he must quickly get himself elected. One of the traditional ways to do this is to resign a party member, creating a vacancy that allows the opportunity for the defeated prime minister to run again in the by-elections. Pakistan the appointment of prime minister is straightforward ordinarily he/she takes an oath of office in front of the president. In Canada, the designated prime minister is sworn in by the Canadian Privy Council Clerk represented by the head of the federal bureaucracy of Canada, who took the oath of office during the reading of the bible (Mahler, 2012). On the other hand in Canada, the prime minister does not necessarily have a fixed period of the term to hold his/her office. Under the responsible governmental system, the Canadian premier remains in office at Her Majesty's pleasure, until he resigns, is dismissed or dies, but in practice, this amounts to as long as he has the confidence of the majority in the House of Commons, but this may go if, for instance, he loses an important bill (Bernie \& Brownsey, 2005). The term of office of the Prime Minister of Pakistan is fixed at five years, as are the national and provincial assemblies. After completing his five years of the term, the process of nominating the prime minister is resumed through general elections. In Canada, the constitutional period of the assembly is limited to five years, but in 2007, an amendment Section 56.1(2) of the Canadian Elections Act limited the term of government to four years, with the election scheduled for the third Monday, after the previous polling date of the fourth year in October. Further in Pakistan elections to the national assembly and provincial assemblies are held simultaneously, but in Canada, each province has its schedule for provincial elections (Newman, 2012). The Prime Minister of Pakistan can be removed from his office then a motion of no-confidence is presented against him in the national assembly of Pakistan. Minimum 20\% members of the National Assembly must present the motion to the speaker in the house and a majority may vote the incumbent prime minister out of office. The prime minister may also resign from his post. In this case, he sends his resignation to the president (Tidridge N., 2011). When the prime minister leaves his entire cabinet will be also be suspended. In Canada at the federal level, a member of the house may explicitly present this motion to the house; also certain bills are deemed that if the incumbent government can't get them passed the prime minister and his cabinet have to resign and the Governor-General may invite someone else, the opposition or a coalition, who can command the confidence of the house to form the government or call for general elections to that house (Mancuso, et al, 2006). In Pakistan, the prime minister's powers have grown significantly with a fragile system of checks and balances through the three branches of government, i.e. the executive, judiciary, and legislature. The Prime Minister of Pakistan is responsible for running the management of the country. He keeps the president informed of the performance of the administrative departments. He has several duties as a leader of the house. He appoints ministers to help him in executive functions. Answering questions in the assembly, official meetings with foreign delegates, and presiding over cabinet meetings all are included within the duties of the prime minister though in Pakistan answering questions in the assembly is rarely done by the prime minister himself. The prime minister is described as a moon among minor stars or as the first among equals in the cabinet. The federal cabinet is the foremost executive body of Pakistan. The prime minister must select them from members of the legislature, of which at most $20 \%$ may be from the senate and the rest from the national assembly. All members of the cabinet take an oath on their appointment as minister (Hussain, 2013). They have their offices in their respective departments in the Pakistan Secretariat. The Secretary of the Cabinet of Pakistan performs his duties as the administrative head of the cabinet division and reports to the prime minister directly. Of course, the cabinet is another important forum of decision-making in the government of Canada. The prime minister chooses the ministers for cabinet, and then is appointed by the Governor-General formally and assigned their respective portfolios and responsibilities. An important aspect of the cabinet is that it is based on the concept of collective responsibility, which means they must publically support all decisions made by the cabinet even if privately they disagree with them (Colebatch \& Hoppe, 2018).

- Legislative: The second branch of the political system is the legislative branch. This is made up of two chambers; which are respectively also known as the upper and lower houses of parliament. The Legislative Branch, after being signed by the Governor-General or the President, introduces reviews, passes, or votes on bills that become laws. The parliament is undoubtedly the exclusive and unique representative of the people and makes law for the country (PIPS, 2014). According to the constitution of Pakistan, under Article 50, the president, the Senate, and the national assembly collectively make up a body which is known as the Council of Advisers or Majlis-i-Shoora. The federal legislative branch of Pakistan is a bicameral, consisting of the lower house or the national assembly and the upper house or the Senate. Canada is similarly bicameral. Under the Constitution Act 1867 Section (17) it is stated that the country will be a parliament consisting of the queen, a lower chamber styled the House of Commons, and the upper chamber the Senate (Palonen M., 2016). Over the years in democratic systems, the Senate has emerged as a necessary organ and stabilizing element of the federation. In Pakistan, the main purpose behind the creation of the Senate (the upper house) is to provide equal representation to all the provinces (Adel, Elmi, \& Taromi-Rad, 2012). The proportion of the population is represented in the membership of the national assembly in each province. Thus, in the Senate equal provincial membership balances the disparity among provinces. The members of the Senate are elected through an electoral college which comprises the provincial assemblies of their respective provinces and the national assembly and the total number 
of members of the upper house is 104. The members of the Senate hold their offices for a term of six years. However, after every three years, half the members of the senate are retired. In Canada, the senate (also termed the upper house) is distributed to provide more or less equal representation to every major region of the country. There are 24 seats each for the Maritime Provinces, Quebec, Ontario, and the Northwestern provinces, six for Labrador and Newfoundland, and one each for the frozen three Northern provinces (Rodger, 2013). The total number is 105 members. The prime minister advises the Governor-General who appoints the senators, who must be over 30 and 75 years is the mandatory age for retirement, also he must be a resident of the area he is representing and there are certain other qualifications to ensure respectability. The Pakistan Senate is chaired by the chairman and deputy chairman of the senate while the speaker chairs the Canadian Senate. In Pakistan senate is the enduring body of the legislature and represents the process of continuity in the legislature (Abbasi A. A., 2018). In Canada, the senate is akin to the House of Lords in the UK and serves as the second forum of soberer and studied thought after the House of Commons where discussions are often confrontational. It studies the House of Commons bills and has the power to approve or reject them or suggest amendments. The senate can also introduce its bills, except for imposing taxes or spending public money which only the prerogative of the House of Commons. No bill or draft can become law without the approval of the senate. Through committee work, the senators also study major economic, legal, and social issues. However, for over fifty years the senate has hardly rejected any bill, though they have recommended changes. It is pertinent to mention that the terms lower and upper houses of parliament do not denote any decrease or elevation in importance. The origin of these terms lies in the history of the parliament in the UK. The House of Lords originally had nobility as members albeit elected, whereas the House of Commons had representatives from the classes below the nobility. So the term denotes either the upper noble class or the lower class of the members. This tradition is reflected in the current terminology (Rodger, 2013). The national assembly is the lower house of the parliament of Pakistan. This is the House of Representatives with 342 members and all the members of the national assembly are directly elected by the people of Pakistan and referred to as MNAs. The people of all provinces and regions are represented in the national assembly according to the proportion of the population. In Canada, the House of Commons is the lower chamber of the parliament and is considered the Centre of political power (Tidridge N., 2011). It is an elected and dominant institution and also called the legislative body, the members are called MPs (members of parliament). The House of Commons consists of 338 members, those are democratically elected directly through plurality votes and each represents an electoral district (like the Pakistani constituencies). The House of Commons endows a bond between Canadians and their parliament. The people of Canada strongly identify themselves with the parliament The MPs make a difference to the country by enacting laws and assisting their constituents (Rodger, 2013). They work to make decisions in Canada's interest within the framework of Parliament and their parties. Some may not agree with decisions but the system gives them the chance to show their displeasure or approval at every federal election. The election of MPs gives Canadian citizens a voice in their country's affairs and in holding the government accountable for its actions. The voter helps the system to become stronger and serve the people better. The constitutional term for the National Assembly in Pakistan and its members is five years unless the national assembly is dissolved or a legislator may resign sooner. However, historically, so far not a single prime minister has been able to complete his term and the assemblies have been dissolved several times. In Pakistan after the members of the national assembly take an oath and assume their seats in the parliament and the president and prime minister are elected, then the elections for the speaker and deputy speaker are conducted by the speaker of the outgoing assembly. The voting is done by secret ballot in the first meeting of the assembly. The office of the speaker may fall vacant for several reasons: he may resign, in which case he will send his resignation to the president; terminates his seat in the assembly; or, of course if he dies. He may be removed if there are impeachment proceedings against him or a motion for a vote of no confidence and the majority of the national assembly vote against him. When such motions are initiated he does not preside over the assembly. He will also have to step down if he loses his seat be loses his seat in the assembly, say if the court declares his election faulty or he is convicted for some crime. The speaker must is to preside over the debates and maintain order and discipline to ensure the rules of the house are observed. He is supposed to conduct the debates fairly and give a chance to all the members of the house to express their views on any matter under discussion, prevent unparliamentarily behaviour and ensure a fair vote count. The speaker of the senate is called the chairman. The speaker represents or symbolizes his chamber when he talks to the Governor-General, monarch, or senate. Whenever a member of parliament or senator enters, crosses the floor, or leaves the house then he/she must bow before the chair of the speaker (James \& Kasoff, 2008).

- Judiciary: The third branch is the judiciary. This includes the judges and courts at both the provincial and federal levels in Canada and Pakistan. The judiciary is one of the most important organs of the government and is not in any way inferior to the others. The institute whose efforts are most effective in establishing a happy and prosperous society is the judiciary. The judiciary facilitates providing fairness to citizens. It protects the fundamental rights of the citizens. It adjudicates disputes, judges offences, punishes criminals, protects the rights of people and organizations, and arbitrates agreements. The judiciary acts from the executive branch independently. Although, the Governor-General appointed judges in Canada on Prime Minister's advice (Rodger, 2013). The Judicial Branch applies and interprets the law and provides advisory advice to the government on legal matters whenever asked. The federal-state requires an independent 
and impartial judiciary. Pakistan is also a federation that is divided into the capital city and four provinces. The judiciary resolves areas where there may be doubt about federal jurisdiction; specifies the powers for the Centre and provinces and adjudicates on intra-governmental cases. In Pakistan, the judiciary is organized in such a way that it is capable of protecting ethical values. The constitution of Pakistan has given the judiciary an elevated position to take important decisions. It has given the Supreme Court and its subordinate courts safeguards to protect its independence (Assembly P. C., 2016). The judicial structure consists of, in ascending order of seniority, civil and magistrate courts, session courts, district courts, provincial high courts, and the country's highest court that is the Supreme Court. Federal courts and some provincial courts as well as, tribunals such as the board of revenue tribunals, banking courts, income tax \& excise courts, and the services court are recognized as well in all the provinces. The Supreme Court seeks solutions to bilateral cases and problems of the federal and the governments of all four provinces in Pakistan. Appeals against the decisions of the four provincial high courts can be filed in the Supreme Court.

\section{Strengths and weaknesses of Pakistan's parliament}

The political system of any state is based on its political culture and no government can be run if it is not in harmony with the aspirations of the nation. Pakistan came into being a democratic state. Pakistan is facing huge problems in the federation, public welfare, language issues, and fiscal matters (Ahmad M., 2017). Pakistan is one of those few states among the developing world and Muslim countries, where the people have repeatedly shown keenness to adopt the parliamentary democratic system and condemned military dictatorships through mass movements. Pakistan emerged under the Independence Act of 1947 passed by the UK parliament. Four days before independence, the first meeting of the constituent assembly was held in Karachi and this could have set the trend for a proper democratic system afterwards, but vested interests and a bias against giving power to the majority previous East Wing of the country prevented this and resulted in the country not getting a proper stable political government-led two faulty constitutions foisted on the people and prolonged periods of military rule that always ended in turbulence (Khalid M. T., 2018). After 71 years of Pakistan's independence, the struggle for the true parliamentary system has not ended and the country's affairs are in a state of confusion. But, the supremacy of the parliament was restored in Pakistan in the first decade of the $21^{\text {st }}$ century bringing hope when the first genuine parliament with a democratic spirit that could resist arbitrary dissolution by the executive institutions was established. This was the $13^{\text {th }}$ parliament in the country and all the previous ones were all subject to manipulation by the power structure in the country in some way or the other (Mahboob H. U., 2020).

According to parliamentary traditions, the President of Pakistan cannot exercise his powers similar to the British Queen in the UK. The president issues his orders on the prime minister's advice. The prime minister makes the decisions and the president imposes them under his name (Bourgault \& Dunn, 2014). The President of Pakistan is responsible for the advice of the cabinet and prime minister in all matters. The president gives the final approval of a bill and makes it a law to be enforced in the country. Thus the first premise of this study is that in both Canada and Pakistan the parliamentary system runs according to parliamentary customs. It is also premised in this research that parliamentary traditions strengthen the parliamentary political system. The legislative process is more or less the same in both Canada and Pakistan: bills are first approved to be taken up, and then considered by both the Senate and the House of Commons/national assembly, respectively, and then assented to on behalf of the Crown/president. Both houses of parliament can initiate the bills for legislation in Canada and Pakistan. But the lower house in both Canada and Pakistan can introduce money bills. A federal bill has to go through three readings in the two chambers of the parliament in both Canada and Pakistan and then it can get the formal status of law.

This study acknowledges that the parliamentary form of government is the most representative and most efficient system of government that is running successfully in different countries. In this system, people believe in parliament because it is the constitutional expression of their political aspirations and the government is accountable to the people for its actions. Parliament safeguards the political views of the citizens and thus provides them with all possible opportunities for more participation in the government. It creates a cohesive and strong party system. Canadians feel that responsible government is better than any system in which the power of the executive is separated from the parliament because responsible government leads to an efficient and stable system that ensures that government and parliament are answerable and accountable to each other (Rodger, 2013). However, the main function of the parliament remains to conduct legislature.

This research also acknowledges that the parliamentary form of government strengthens democracy because the participatory aspirations of the people want to make their elected body, the parliament supreme. In Pakistan, the process of democracy is at a crossroad. Certain segments in the population feel an exclusive authoritarian and dictatorial system is more beneficial to them (Ahmad M., 2017). But in the future democratic traditions will demand a more positive vision and building consensus. The fact is that the democratic parliamentary system of Pakistan has the overwhelming support of the majority, but the goal remains elusive because of the power structure (Khalid M. T., 2018). However, despite some controversies, the general elections of 2008 tried harder to strengthen parliamentary democracy in Pakistan through providing a good political environment to people and introducing better rules of the electoral procedure. On the other hand in Canada citizens elect 
people to different levels of government to represent them in the decision and that is known as representative democracy. Canada, UK, and the US are prime examples of representative democracy (Rodger, 2013).

\section{Strengths and weaknesses of the Canadian parliament}

In Canada, a confederation of three provinces was formed and granted dominion status with a central parliament of Canada through the 1867s Constitutional Act. It was further added to by Canadian and British laws that have a constitutional effect (e.g., the Canada Elections Act) and certain unwritten principles known as constitutional conventions (Tidridge N., 2011). This parliament was comprised of the monarch (acting through the Governor-General), the Senate, House of Commons. It outlined the federal structure the judiciary and taxation systems. This Act was passed on $29^{\text {th }}$ March 1867 and came into force on $1^{\text {st }}$ July of the same year (James \& Kasoff, 2008). The first general elections of the dominion of Canada took place later that summer and on $6^{\text {th }}$ November 1867 and for the first time the House of Commons assembled at Ottawa. James Cockburn, MP was elected as the first speaker of the house and the next day, on $7^{\text {th }}$ November the dominion parliament met with the Governor-General Lord Monck, to hear the inaugural speech from the Throne in Canada (Rodger, 2013). On $1^{\text {st }}$ July, a law enacted by the Parliament of Canada came into being. But it would be ambiguous and misleading those parliamentary institutions of Canada was initiated at the time of confederation because amendments and conventions continued to be enacted and the other provinces joined the confederation gradually. The present Canadian constitution consists of the 1867 and 1982 Constitutional Acts (Tidridge N., 2011). The Governor-General of Canada has numerous responsibilities that are primarily ceremonial, including declarations of war, signing treaties, signing the letters of credence for diplomatic appointments, representing Canada abroad, granting Canadian coat of arms, and managing the honours list of Canada (Herman, 2016). All these responsibilities are performed in the queen's name. The Governor-General fulfills the functions and responsibilities of the queen at the national level and lieutenant governors do the same at the provincial levels (James \& Kasoff, 2008).

In Canada's parliamentary system, a regular parliamentary session is divided into session days and adjournments. The expansion of parliament concludes a special session. When Parliament is reconstituted, the new session starts with Throne speech, announcing the legislative program of the government for the session. Dissolution can take place at any time within five years which indicates the end of Parliament and on the Prime Minister's advice is invoked by the Governor-General. The dissolution includes the formation of a newly elected parliament and an election afterwards. Parliamentary privilege makes sure that parliament will not only control the fact that it can debate, but that individual members of parliament will also enjoy full freedom of speech. Written rules of parliament guarantee the right of opposition governors to criticize the party without fear of reprisals. The privilege of whatever is said in the committees and chambers also protects the legislators from slander (Lauise, 2013).

The Canadian prime minister did not appear in the written Constitution until 1982. The constitution still does not contain one syllable about the qualifications that a prime minister needs; the method of his election or removal, also nothing is mentioned about his powers (except for calling constitutional conferences). The only thing mentioned is the provision of accommodation/residence, pension, and salary for the person holding the recognized post of First Minister. There is no written law that requires any minister or the Prime Minister to get a seat in the Parliament (James \& Kasoff, 2008). There is nothing in any law to say that a government on a matter of confidence must either seek a fresh mandate or resign in the House of Commons. These are just customs that have become mandatory. However, in Canada, the precise meaning of the written constitution is settled by the courts (Rodger, 2013).

The courts especially the "Judicial Committee of the British Privy Council", which was the High Court in Canada till 1949, have generally interpreted the Constitution Act, 1867, expand the provincial powers and narrow federal powers. The result is that perhaps Canada has become the mainly decentralized federation in the world. However, the fact that the powers not specifically mentioned have been automatically taken by the federal government gives it enough leeway and strength to meet many of the changed and distorted conditions the years have brought. The politics of Canada function within a framework of democratically oriented federal and parliamentary democracy with strong traditions. Canada is described as a 'full democracy, as compared to Pakistan, with a tradition of an egalitarian, liberalism and moderate political ideology (James \& Kasoff, 2008). The principle of responsible government in Canada has evolved through tradition from a parliament controlled by a monarchy to one of merely honouring and averring fealty to Regina and imbued public representation and accountability into the political system. Resign which the executive is accountable for its actions to an elected legislature. Besides, a responsible government has benefits to being accountable to citizens and allows different levels to be accountable to each other (

Thus Canada is a constitutional monarchy and a parliamentary democracy. This means that the Government of Canada is made up of a party or group of parties that can gain and retain the confidence of the legislature and that the sovereign means the head of state is bound by the Constitution (Tidridge N., 2011). There are regular free and fair elections, a 'responsible' judiciary, and guaranteed freedom and set of rights. Hence, Canada advances democracy by enhancing and promoting the 
full involvement of all Canada's citizens in the processes of decision-making and institutions that affect their lives. This includes marginalized groups, youth, and women. Democracy, respect for diversity, peaceful pluralism, human rights, government accountability, and inclusiveness are core values that shape the democracy in Canada. Despite these strengths, there are some weaknesses in Canadian parliamentary democracy such as lack of accountability and transparency in Canadian politics but it has been overcome by the competency of the executive authority day by day.

\section{Comparative analysis}

Most topical subjects deal with the US, China, India, etc.: great nations who are doing a bad job. I have chosen Canada because it is just a nation doing a good job in creating a congenial and prosperous environment for its people. This study analyzed the legislative process in Canada and Pakistan and presented a comparative study of the parliamentary system of both these two countries. In both Canada and Pakistan, the House of Commons and the national assembly respectively are considered the most active component of the parliament and pass legislature, resolutions and keep a check on the government through numerous parliamentary committees, Question Hour, adjournments motion and debates. These debates approve decisions regarding policies drafted by the government and ensure they are beneficial for the people and the state. To become law in Pakistan, every House of Parliament must go through a legislative process that includes twelve or thirteen steps, including three readings in both the Senate and the National Assembly, after which presidential approval will be passed. The constitution of Pakistan regulated this procedure and the rules of procedure of the relevant House. Both houses of the parliament can initiate the bills for legislation (Ahmad M. T., 2017). But the lower house of the parliament has an edge over the upper house by dint of money bills. However, both houses of the Parliament of Pakistan work with full cooperation for legislation. The bills which are submitted by the government are discussed first in one of the two chambers.

However, the comparative study of two parliamentary systems makes it clear that the parliamentary system of Canada is open as well as democratic in nature and that has created a good and orderly environment, established nationhood in a disparate population with many provinces and Canada has become one of the developed countries of the world. People from all over consider it to be a good place to live (Rodger, 2013). The study also argues that the parliamentary system of Canada functions more smoothly and is more congenial and effective than the Pakistani system. However, both the governmental system of Canada and Pakistan allow for an efficient, accountable, and stable government. The parliamentary system of Canada is designed to ensure that legislative bills are considered carefully and benefit the people and society. The Canadian head of the state is the queen which makes it different from the Pakistani parliamentary system where the president is the head of the state but performs the same as the queen performed in a titular manner. Canada's Queen is also the queen of New Zealand, Australia, and Britain, and a host of other scattered countries around the world from Tuvalu, Grenada to Papua New Guinea and the Bahamas but without any power. Every governmental act in many of these countries is signed in the queen's name but the power for every action comes from the people of these countries.

The main lesson to be comparatively analyzed by this study is that one problem that is common to both nations is provincial imbalance. In the last half of the $20^{\text {th }}$ century, there was a secessionist movement in Quebec, because of its majority French population. Canada handled this by holding a referendum which the non-secessionists won by a narrow margin. More recent polls show a decline to $22 \%$ in people from Quebec who want to secede. Apart from this, there are 12 other provinces and territories with different conditions and imbalanced development. However, overall it can be said that Canada has accommodated its provinces effectively by its responsible government democratic system and granting maximum autonomy. Another factor that is a major problem in Pakistan but not so in Canada is the branches of government overstepping their jurisdiction. Again Canada with its long tradition of a responsible government and unwritten laws does not view this as a problem, rather they have confidence in their democracy and know such actions represent the accountability in their system and are taken for the benefit of the people and strengthening of the system, whereas in Pakistan it indicates one branch of the government grabbing more power or one province depriving another. Thus we can see the value of Canada's long history of democracy and its traditions of political accountability and delineation of powers. In Pakistan democracy has only gained real impetus in the first decade of this century and we have a constitution in which almost all important matters are carefully written and thought out. The political parties are doing their jobs and there is no doubt that the houses are proving useful. Therefore in closing this study concludes that our democratic system as per the constitution and the institutions as they stand have the potential to deliver beneficial results. The problem lies in a lack of confidence in the democratic tradition and intolerant attitudes among segments of the people. There is no real support of the democratic process at various levels of the government institutions and among powerful segments of the population. The only solution to this is that our narrative must give more importance to democracy and it should be accepted as the ideal this country wants to achieve.

The position of democracy in a country can be assessed by the presence of an opposition party. The existence of the opposition is very important in protecting the true spirit of democracy. Opposition is very helpful in fostering high democratic traditions. For instance, in Britain, the opposition has a special position and is regarded with as much respect and importance as the ruling party. There should be no propaganda or persecution by the government against the opposition. The opposition should get fair representation in all the committees which the house creates for the legislature. An opposition 
remains active and points out flaws in the policies and monitors the weak points of the ruling party. Whenever the administration makes a mistake the opposition criticizes it. The opposition presents a different view on problems and issues that should be considered. The opposition part is constantly monitoring the performance of the members of the cabinet. However, the opposition does not just criticize. Whenever the ruling party takes a constructive step then the opposition also supports it. This role is performed by the opposition party in Canada (Tidridge N., 2011). In Pakistan the opposition is also active, and in many aspects, the norms of democracy are followed and more are slowly developing but the attitude on both sides is too intolerant. The ruling party uses the government machinery to stifle and persecute the opposition members and often the criticism by the opposition is not just on policy matters but accusations of various kinds. Frankly, not enough importance is given to the debates in parliament and too much to shows strength and sloganeering. Both in Pakistan and Canada, the leader of the party with the second-largest number of seats in the house is nominated officially as the opposition leader. The opposition does a job to make sure the ruling party considers their legislation carefully and different views on significant proposals should be defended and expressed publicly.

Another feature that is common in both the Canadian and Pakistan legislature is the committee system. Standing committees play a very crucial role to study issues in depth. The parliament has instituted many committees, which perform such actions that cannot be performed competently during the period of Question Hour in debate. The committee members are selected from among the parliamentarians. The committee's work is an important part of the member's employment and legislative process. Committee members can review the bill in more depth in the House, which includes a full timetable and a large group of people. Parliamentary Committees study key issues such as federal departments, spending plans, finance, and health. Due to the limitations of committees and sub-committees, one member of the committee can sit more than one. Besides, Committees often sit for long hours and meet regularly. They frequently consult with the experts and public and members have to travel sometimes across the country. When a draft arrives in the house for the legislature, often the draft is submitted to a committee after a few steps, namely introduction, and first reading. The committee reviews the pros and cons and each member enters his or her remarks on it and sends the draft back to the house. Unlike the American committees, the committees in Pakistan and Canada do not have the power to abolish any draft by themselves. The committees must report positively or negatively on each draft and resubmit it to the house. Both the Senate and the House of Commons spent most of the day-t0-day working in Canada in standing or special committees. The work done by the committees helps to inform the MPs about the concerns of the voters (Rodger, 2013). Besides, the parliamentary committees interact with citizens, to elected representatives delivering their voices directly. Although in Parliament the Question Hours often receive full coverage, committees do not report valuable work. However, most of it is available to the public because the parliament recorded it.

\section{CONCLUSION}

It is concluded and believed by analyzing the research topic that the Canadian parliamentary system is more effective and democratic and functions as compared to Pakistan's parliamentary system. Because the main negative point seems in the Pakistani system are the prolonged periods of military rule and proxy military rule which encouraged inefficient policymaking processes. Due to the principles of responsible government, parliamentary systems are superior as they guaranteed that each body/entity of the government is accountable for the other. Hence, by following a stable, democratic, and an effective system, Canada with a parliamentary system was the first federation and designed on the British Westminster model, including a bicameral legislature. There are three main characteristics of such a democratic government: Firstly, the executive depends on majority support in the Lower House and accountable to parliament. According to the principle of parliamentary democracy practically, there is a fusion of powers between the prime minister and the executive and the PM led by the majority party. As a result, the prime minister holds a key position in the political system. His leadership is based on his symbolic relationship with his party and his aptitude to manage the parliamentary agenda. Besides, the Prime Minister of Canada is also able to wield executive power in their own hands, in a German chancellor democracy, and the prime ministers of the provinces enjoy comparative leadership in their respective regions. The Second one is sovereignty is vested in the parliament. This system has the power to speak of the last resort. The Supreme Court of Canada has the power to decide whether a law infringes the "Charter of Rights and Freedoms". Though, the principle of parliamentary sovereignty applies to the executive that makes it subject to the will of the House. Thirdly, members of the parliament are elected according to the pro-majority post system in the first clear elections. With a growing number of effective parties, is not guaranteed a clear one-party majority in Canada. Yet, parties prefer minority governments to coalitions, and one-party governments still exist as conventions at the provincial and federal level in Canadian politics. As is the case in other democratic federations, the Prime Minister's power is not limited effectively, with his cabinet by the second Chamber. In actuality, the Canadian Senate was created with the British House of Lords in view, although it did not retain peerage membership, but made appointments instead. Despite the power of the House of Commons to veto any legislative decision, the Senate de facto is an advisory body, a body that provides advice and examines bills.

\section{RECOMMENDATIONS}

This study suggested some recommendations for strengthening the parliamentary democracy in Canada and Pakistan. Both 
parliaments have the best opportunity to work more competently. The ruling party must build an atmosphere of mutual understanding with the opposition parties. On the other hand, the political parties must also work more efficiently, effectively to create harmony with the opposition parties. The supremacy of parliament must be maintained. No one is above the law. The constitution must be the supreme law of the land in the true sense of the word. Parliament should complete its term at every cost. Besides, with the coordination of the opposition parties, the majority party should play an active role, especially the committees should share with the opposition parties. The opposition in parliament should play a positive role in strengthening democracy. The parliamentary committees on interest should work more open and national security issues should be trialled publically on with an extensive variety of government and non-government spectators. Parliament should be used as the most important key for check and balance institutions as it is the most important element of the system of national governance. Committees should have investigated the errors of intelligence activities. Senior civil service activities should be overseen by parliamentary committees. The committees should have submitted their reports promptly to implement them in their true spirit. The cabinet should exercise political power and the opposition should examine it to balance the balance of power in the public interest.

\section{LIMITATIONS OF THE STUDY}

This study is an addition to exploring the boundaries of comparative politics. The Comparative Study is the basic tool to examine the facts and valuable recommendation for the future to strengthen parliamentary democracy, particularly in developing countries. This research explores the core policies, decisions, changes, and thereafter effects of the parliamentary system of Pakistan and Canada. This study is an addition to exploring the boundaries of comparative politics. The Comparative Study is the basic tool to examine the facts and valuable recommendation for the future to strengthen parliamentary democracy, particularly in developing countries. This research explores the core policies, decisions, changes, and thereafter effects of the parliamentary system of Pakistan and Canada.

\section{IMPLICATIONS OF THE STUDY}

There are research gaps in previous research information and this research fills the gap through collected information and data from the most recent development. This research focused on major issues and challenges which now a day's Parliament of Canada and Pakistan faces and provides suitable suggestions to resolve these issues and to overcome these challenges. Furthermore, the comparison between the two parliaments is helpful to adopt democratic traditions for the development of the parliamentary role in dramatic political systems.

\section{ACKNOWLEDGEMENT}

Financial support from any corner is not involved.

\section{AUTHORS CONTRIBUTION}

Sidra Akram: wrote the paper and analyzed the data.

Mian Muhammad Azhar: devised the main idea and research design.

Shakil Akhtar: Edited the manuscript.

Husni Mubarak: Proofreading.

Muhammad Ikram-ul-Haq: contributing to data collection.

\section{REFERENCES}

1. Abbasi, A. A. (2018). The Parliament of Pakistan an Analytical Research Study of Strength, Weaknesses, Opportunities and Challenges. International Journal of South Economy, 2 (2), 119-143. https://doi.org/10.18576/ijye/020204

2. Adel, G. H., Elmi, M. J., \& Taromi-Rad, H. (2012). Muslim Organisations in the Twentieth Century: Selected Entries from Encyclopaedia of the World of Islam. London: EWI Press, Encyclopaedia of the World of Islam.

3. Ahmad, M. T. (2017). National Parliaments: Pakistan. Islamabad: The Law Library of Congress, Global Legal Research Center.

4. Ahmed, N. (2020). Parliaments in South Asia: India, Pakistan and Bangladesh (illustrated ed.). Chittagong, Bangladesh: Routledge Studies in South Asian Politics. https://doi.org/10.4324/9780429465413

5. Andre Barnes. (2019). The Legislative Process: From Government Policy to Proclamation. Ottawa, Canada: Parliamentary Information and Research Service, Library of Parliament.

6. Assembly, P. C. (2016). The Constituent Assembly (Legislature) of Pakistan Debate. Manager of Publications, University of Minnesota. 
7. Barnes, A. (2012). The legislative process: from government policy to proclamation (Revised ed.). (F. English, Trans.) Ottawa: Library of Parliament, Parliamentary Information and Research Service.

8. Bernie, L., \& Brownsey, K. (2005). Executive Styles in Canada: Cabinet Structures and Leadership Practices in Canadian Government. Toronto: University of Toronto Press. https://doi.org/10.3138/9781442674707

9. Bourgault, J., \& Dunn, C. (2014). Deputy Ministers in Canada: Comparative and Jurisdictional Perspectives. Toronto: University of Toronto Press. https://doi.org/10.3138/9781442665170

10. Bourinot, J. G. (2008). Parliamentary Procedure and Practice in the Dominion of Canada (reprint ed.). (T. B. Flint, Ed.) The Lawbook Exchange, Ltd.

11. Burki, S. J. (2010). Historical Dictionary of Pakistan (2, illustrated ed.). (J. Woronoff, Ed.) Minnesota: Scarecrow Press.

12. Colebatch, M., \& Hoppe, R. (2018). Handbook on Policy, Process and Governing. Australia: Edward Elgar Publishing Limited. https://doi.org/10.4337/9781784714871

13. Commons, H. o. (2017). Guide to the Canadian House of Commons. Ottawa: Library of Parliament.

14. Ali,G, \& Hussain,E. (2020). Perspectives on Contemporary Pakistan: Governance, Development and Environment (illustrated ed.). UK: Taylor \& Francis Group. https://doi.org/10.4324/9781003007784

15. Green, H. J. (2017). The Judicial Role in Court Administration in Canada:Striking the Balance Between Judicial Independence and Effective Court Management. Larbador: Oxford University Press.

16. Hall, K. L., \& McGuire, K. T. (2005). The Judicial Branch (illustrated ed.). Ottawa: Oxford University Press.

17. Hashmi, D. R. (2018). Parliamentary Democracy and the Issue of Institutional Jurisdiction in South Asia (The Case of Pakistan). Journal of Political Studies, 25 (2), 133-146 ISSN- (Print)1994-1080 E-ISSN (Online):2308 -8338.

18. Heitshusen, V. (2017). The Speaker of the House: House Officer, Party Leader, and Representative. Congressional Research Services.

19. Herman, M. B. (2016). Prime Minister and Cabinet in Canada: An Autocracy in Need of Reform? Journal of Canadian Studies, 35 (4), 60-79. https://doi.org/10.3138/jcs.35.4.60

20. Huntington, S. P. (2012). The Third Wave: Democratization in the Late 20th Century. Norman. Oklahoma: University of Oklahoma Press.

21. James, P., \& Kasoff, M. J. (2008). Canadian Studies in the New Millennium (illustrated ed.). Toronto: University of Toronto Press.

22. Johnston, L. W. (2012). Politics (Canadian Edition): An Introduction to the Modern Democratic State (4th ed.). Toronto: University of Toronto Press.

23. Khalid, M. T. (2018). PARLIAMENT a symbol of protecting the rights and will of the People. Pakistan Institute for Parliamentary Services, 5 (06), 21-24. https://doi.org/10.1093/oxfordjournals.pa.a051513

24. Kokhar, N. I. (2017). Civil-Military Relations in Pakistan: Musharraf's Era (1999-2003). Islamabad: National Defence University Islamabad.

25. Koop, R., Bastedo, H., \& Blidook, K. (2018). Representation in Action: Canadian MPs in the Constituencies. UBC Press.

26. Lauise, A. (2013). Parliament's Role in Pakistan's Democratic Transition. Asia Report, 249. New York: International Crisis Group Working to Prevent Conflict Worldwide.

27. Loughlin, J., Kincaid, J., \& Swenden, W. (2013). Routledge Handbook of Regionalism \& Federalism. Ottawa: Routledge. https://doi.org/10.4324/9780203395974

28. Hussain, M. (2013). Institutional Influence in Pakistan: Bureaucracy, Cabinet and Parliament. Asian Social Science, 9 (7), 50-62. https://doi.org/10.5539/ass.v9n7p173

29. Mahboob, H. U. (2020). The Parliament of Pakistan: a History of Institution-Building and (un)Democratic Practices, 1971-1977. UK: Oxford University Press.

30. Mahler, G. S. (2012). New Dimensions of Canadian Federalism: Canada in a Comparative Perspective (1st ed.). Alberta: Fairleigh Dickinson Univ Press.

31. Malcolmson, P. (2012). The Canadian Regime. (R. Myers, Ed.) Toronto, Canada: University of Toronto Press.

32. Mancuso, M., Price, R. G., Wagenberg, R. H., Wagenberg, R., \& Price, R. X. (2006). Leaders and Leadership in Canada (illustrated ed.). Ottawa: Oxford University Press, The University of Michigan.

33. Newman, S. L. (2012). Constitutional Politics in Canada and the United States. USA: SUNY Press.

34. Oldenburg, P. (2011). India, Pakistan, and Democracy. Hong Kong: Routledge Taylor and Francis Group. https://doi.org/10.4324/9780203847152

35. Palonen, M. (2016). The Politics of Parliamentary Procedure: The Formation of the Westminster Procedure as a Parliamentary Ideal Type (2 ed.). Berlin, Toronto: Barbara Budrich. https://doi.org/10.2307/j.ctvdf02wr

36. PIPS. (2014). National Assembly of Pakistan. Islamabad: National Assembly Secretariat.

37. Rodger, E. (2013). How Does the Canadian Government Work? London: Crabtree Publishing Company. 
38. Schoburgh, E. R. (2016). Handbook of Research on Sub-National Governance and Development. Australia: IGI Global. https://doi.org/10.4018/978-1-5225-1645-3

39. Smith, G., Hincks, S. F., \& Blachford, F. R. (2017). The Political Destiny of Canada. California: Willing \& Williamson, The University of California.

40. Sultana, T. (2017). Montesquieu's Doctrine of Separation of Powers:A Case Study of Pakistan. Journal of European Studies , 2 (2), 55-77. https://doi.org/10.2307/j.ctv173f229.7

41. Tidridge, N. (2011). Canada's Constitutional Monarchy (illustrated ed.). London: Dundurn.

42. Todd, A., \& Horatio, A. (2015). Parliamentary Government in the British Colonies (2nd ed.). (A. H. Todd, Ed.) Toronto: Longmans, Green, and Company.

43. Tushnet, M., \& Khosla, M. (2015). Unstable Constitutionalism (illustrated ed.). New York, USA: Cambridge University Press. https://doi.org/10.1017/CBO9781107706446

44. White, W. L., Nelson, R. C., \& Wagenberg, R. H. (2011). Introduction to Canadian Politics and Government (7th ed.). Ottawa: Harcourt Brace Canada, Northwestern University.

45. White, W. L., Wagenberg, R. H., \& Nelson, R. C. (2011). Introduction to Canadian Politics and Government (5th ed.). Holt, Rinehart and Winston of Canada.

46. Whittington, M. S., \& Loon, R. J. (2011). Canadian Government and Politics: Institutions and Processes (5th, illustrated ed.). McGraw-Hill Ryerson Limited, Pennsylvania State University.

47. Zaka, M. R. (2018). Discover the Parliament of Pakistan. Islamabad: Pakistan Institute for Parliamentary Services. 